\title{
现代士木工程的施工管理问题分析
}

刘阳

连云港市锐城建设工程有限公司

DOI: $10.18686 / \mathrm{bd} . v 1 \mathrm{i} 9.819$

[摘 要] 土木工程施工是一项非常复杂的生产活动。它涉及的范围十分广泛, 需要处理大量的复杂的技术问题, 耗费大量 的人力, 耗费大量的物资, 动用大量的设备。为了保证施工的顺利进行, 保证施工在规定的时间内完成, 因此, 必须对土木工 程施工进行有效的科学的管理。

[关键词] 土木工程;技术;安全与管理;施工现场

土木工程的施工管理是施工企业对所实施的工程项目 进行全过程、全方位的规划、组织、控制与协调的生产行为, 是伴随着施工企业管理体制改革和招投标制的推行而走进 我国的先进的施工管理方法和管理手段。日益发展的土木
工程施工管理的标准对于施工企业提出了更为严格的要 求, 强化施工项目管理, 改变了以往在施工项目管理上陈旧 的管理思想、管理方式和管理方法, 完全按照《工程施工项 目管理规范》的规定, 实施了新型的土木工程施工项目管理 
模式。下面笔者就当前土木工程施工的管理谈几点看法。

\section{1 我国土木工程施工中存在的问题}

1.1 工程监理制度不完善。由于目前我国的工程监理制 度不够完善, 加之工程监理员工素质不高, 缺乏实际经验, 使得工程质量得不到保障,存在十分多的问题,导致房屋倒 塌,豆腐渣工程的产生, 给人类的人身安全造成了非常大的 损害。

1.2 土木工程质量的责任制落实不到位。土木工程管理 中最主要的问题之一就是土木工程的责任制度与设计质量 不相符, 存在十分大的误差, 导致土木工程设计相对单一。 譬如,开发商要求添加项目, 这就使得工程设计需要发生改 变或者增加, 这些情况的出现也要求施工单位事前列入包 干,但是由于这些问题不属于施工单位可以控制的。因此, 导致施工单位不能很好地完成施工质量。

1.3 土木工程招标管理不规范。由于我国在土木工程管 理方面的相关制度相对滞后, 很多规定不够规范。比如, 在 招标过程中存在严重的弄虚造假的现象, 加之现在很多地 方存在严重的地方保护政策，这就直接影响到土木工程招 标的质量; 还有土木招标承发包的价格不够合理,导致很多 不正当的竞争关系,有的大大低于竞标工程的成本价。这种 不规范的招标管理, 使得施工单位在施工过程中存在严重 的偷工减料现象,严重影响工程质量。

1.4 工程管理中项目法人制度存在缺陷。就现在我国的 土木工程管理制度来看，工程管理中项目法人制度存在十 分多的问题。由于工程施工建设的多样化,有的法人制运作 是集项目筹集、建设管理、运营、还贷一体化的,加之我国的 国有企业管理者是由上级任命的，一个管理者不可能在一 个企业长期的工作下去, 总是不定期的更换工作环境, 这种 短期工作的存在导致土木工程企业的发展受到一定的影 响, 十分不利于企业的发展, 也给土木工程项目管理的诸多 方面带来很多麻烦。

1.5 土木工程合同管理不规范。目前土木工程管理中的 好多合同都存在许多不平等的条约，尤其相对于甲方来说 很不公平。现在使用的土木工程的相关合同都是由国际咨 询工程师联合会编写的，这些合同都是用在外资企业和一 些水利水电和大型公路的建设上。然而这些条款都是十分 苛刻的,有些施工单位为了能够争取到这个项目,可以完全 认可甲方拟定的合同文本，这就使得施工方损失了很多利 益, 在实际的工程中得不到相关的赔偿, 也很容易造成实施 管理十分困难。还有一些施工单位言辞不一,很多承诺在实 际施工中都不能完成，导致土木工程项目管理达不到相应 的效果。

\section{2 施工项目质量管理}

2.1 建立质量保证体系。为全面系统地把质量工作落到 实处,当务之急是建立切实可行的质量保证体系。同时,施 工企业依据质量保证模式,建立自己的质量保证系统,编写 质量手册, 制定质量方针、技师目标, 使之更具有指令性、系
统性、协调性、可操作性、可监测性。

2.2 人、材料、施工机械的控制。首先人是质量的创造 者, 质量控制应以人为核心, 把人作为控制的动力, 调动人 的积极性、创造性,增加人的责任感, 树立质量第一的观念。 其次,材料是构成建筑产品的主体。显然在施工项目中, 对 材料的质量控制是举足轻重的。最后, 施工机械是实现施工 机械化的重要标志, 是现代化施工项目中必不可少的因素。

2.3 控制施工环境与施工工序。在土木工程施工中, 影 响工程质量的环境因素很多, 有工程技术环境, 如工程地 质、水文、气象,环境等;工程管理环境,如质量保证体系、质 量管理制度; 劳动环境, 如劳动组合、作业场所、工作面等。 因此, 根据工程项目的特点和具体条件, 应对影响质量的环 境因素, 采取有效的措施严加控制, 尤其是施工现场, 应建 立文明施工和文明生产的环境,保持材料工件堆放有序, 道 路畅通,为确保质量和安全创造良好的条件。

\section{3 加强设备管理}

现代土木工程施工企业跨度大、范围广、领域多、种类 全, 如果大量购置机械设备, 必然会造成企业资产的浪费, 所以，在施工中应根据企业内部项目之间的特殊性和时间 差异,按照“技术上先进,经济上合理,施工上适用,安全可 靠”的原则对项目所需机械进行管理。

3.1 增强核算意识, 提高成本管理水平。在土木工程施 工中, 施工企业要加强材料采购、人工费支出以及项目预算 等几个环节的管理工作，使项目成本的预测、控制落到实 处,解决项目管理体制中 “包盈不包亏”的问题。要加强定额 管理,做到用定额编制计划, 用定额组织生产, 用定额核算, 使定额真正成为提高经济效益的科学工具。还要认真贯彻 实施《企业财务通则》和《企业会计准则》, 强化财务约束和 审计监督,压缩不合理的资金占用和开支,降低管理费用, 提高资金运作效率; 要制定企业内部财务管理办法, 扭转帐 物不符、财产不准、成本不实、虚盈实亏等问题; 要培养利润 动机，构造积累机制，控制消费基金的过快增长，增强企业 发展后劲。

3.2 施工项目安全生产与文明施工的管理。所谓土木工 程施工项目安全管理, 就是施工项目在施工过程中, 组织安 全生产的全部活动,通过对生产因素的具体控制,使生产因 素不安全的行为和状态减少或消除, 不引发事故, 从而保证 施工项目的正常运行。

制定安全管理措施: 加强施工项目的安全管理,制定确 实可行的安全管理制度和措施十分重要。它是管理的方法 和手段, 对生产各因素状态的约束和控制, 根据施工生产特 点, 安全管理也具有明显的行业特色。要落实安全责任, 实 施责任管理,加强安全教育,例行安全检查。

\section{4 坚持遵约守信,强化合同管理}

企业要面向市场, 就要通过严格履行工程承包合同,按 期按质交工和良好的售后服务来提高企业知名度。要提高 编制合同的水平,确保合同的完整性;项目的管理要以工程 
项目合同条款规定的工期、质量为目标, 科学有效地组织施 工生产; 总承包企业要与各分包单位签订总分包合同, 总包 企业要对工程全面负责,分包单位对总包单位负责。此外, 还要学会工程索赔的方法和技巧,用合同约束发包方, 依靠 合同保护自身的合法权益, 努力在市场经济中建立承包商 自主经营, 自负盈亏的商品生产者和经营者的地位, 实现建 筑施工企业向承包商的转变。

\section{5 强化施工现场管理}

施工现场管理水平是反映企业管理水平高低的窗口， 要通过严格的岗位责任和健全的规章制度来约束现场管理 人员和操作人员, 严肃工作纪律, 堵塞管理漏洞。要不断改 进施工机具和作业手段, 重视现场职工生活, 改善现场作业 环境。企业要从现场文明施工抓起, 做了对“脏、乱、差”施工 现场的整顿工作。要对每一个工程项目进行检查排队,对管 理混乱的在建工程,该停工的停工, 该警告的警告,使现场 管理达到“环境整洁、纪律严明、物流有序、设备完好”, 努力 使现场管理水平登上一个新台阶。
土木工程的施工管理还有很多新的东西需要探讨, 只 有我们的同行在工作中善于发现新的问题, 并为之努力解 决, 就一定能使土木工程施工中的管理问题的解决形成一 套好的解决办法。

\section{6 总结}

总的来说，土木工程施工的管理极大程度地反映了该 施工单位的施工质量与水平, 因此为了避免在施工的管理 上出现技术不足、进度落后、环境危害等问题, 就需要从自 身出发控制进度、采用先进的施工设备,控制环境危害等方 式加以改进, 全面提高施工管理水平, 保证施工的效率与质 量, 确保高质量地按时交工。

\section{参考文献:}

[1]万青,高校贷款的风险及其控制[J].浙江金融,2004 (5)

[2]曾华锋,对我国高等学校等资情况的分析[J].事业 财会, 2001(1) 